\title{
METODE INQUIRI DALAM MENINGKATKAN KONSEP BERPIKIR MAHASISWA PADA MATERI SISTEM BILANGAN REAL
}

\author{
Sudarsono* \\ ${ }^{1}$ Program Studi Pendidikan Matematika, STKIP Bima \\ "Email korespondensi: sudarsonolanda123@gmail.com
}

\begin{abstract}
ABSTRAK
Fenomena pendidikan di Indonesia, selalu menghadapi kurikulum yang selalu berubah setiap periodenya, sehingga menuntut para pendidik untuk terus menggembangkan ide kreatif terkait cara penyampaian materi yang baik dan benar. Dari kurikulum yang ada sekarang ini, dapat dilihat tingginya ekspektasi pemerintah yang tertuang dalam kurikulum tersebut, berbanding terbalik dengan realita nyata yang ada dilapangan sejauh ini, dimana sekolah menengah dan sekolah tinggi-pun masih mengunakan metode lama yang ditengarai dapat menurunkan standar pendidikan. Hal ini dikarenakan ketidaktepatan pendidik dalam merancang dan melaksanakan pembelajaran menjadi salah satu faktor penyebab hasil belajar matematika menjadi rendah. Kesulitan peserta didik dalam mempelajari matematika di sekolah, disamping disebabkan oleh sifat abstrak matematika itu sendiri juga disinyalir disebabkan oleh pendidik yang kurang tepat dalam merancang dan melaksanakan pembelajaran matematika di kelas. Proses belajar mengajar seperti inilah yang tidak mendorong mahasiswa berpikir kritis dan berkreatifitas, hal ini tidak sesuai dengan hakikat pribadi mahasiswa sebagai subjek belajar yang lebih tinggi. Dengan dasar itu, pembelajaran mahasiswa harus membangun sendiri pengetahuan mereka melalui keterlibatan aktif dalam proses belajar mengajar, mahasiswa sebagai pusat kegiatan pembelajaran bukan dosen. Apalagi jika dikaitkan dengan era revolusi industri 4.0 dimana manusia dituntut berpikir kritis dengan memanfaatkan media dan teknologi terbarukan abad ini.
\end{abstract}

Kata kunci: Metode Inquiri, Konsep berpikir, Sistem Bilangan Real

\begin{abstract}
The phenomenon of education in Indonesia, always faces a curriculum that is always changing every period, so it requires educators to continue to develop creative ideas related to how to deliver good and true material. From the current curriculum, it can be seen that the high expectations of the government contained in the curriculum are inversely proportional to the actual reality in the field so far, where secondary schools and high schools still use old methods that are thought to reduce education standards. This is because the inaccuracy of educators in designing and implementing learning is one of the factors causing low mathematics learning outcomes. Difficulties of students in learning mathematics at school, besides being caused by the abstract nature of mathematics itself is also allegedly caused by educators who are less precise in designing and implementing mathematics learning in the classroom. This teaching and learning process does not encourage students to think critically and creativity, this is not in accordance with the personal nature of students as subjects of higher learning. On that basis, student learning must build their own knowledge through active involvement in the teaching and learning process, students as centers of learning activities rather than
\end{abstract}


lecturers. Especially if it is associated with the era of industrial revolution 4.0 where humans are required to think critically by utilizing renewable media and technology this century.

Keywords: inquiry method, thinking concept, real number system

\section{PENDAHULUAN}

Berbagai upaya telah banyak dilakukan untuk meningkatkan kualitas pembelajaran matematika, baik itu dilakukan oleh pemerintah melalui Dinas Pendidikan beserta jajarannya maupun oleh berbagai pihak yang punya kepedulian terhadap kualitas pendidikan secara umum dan kualitas pembelajaran matematika khususnya. Upaya itu antara lain penataranpenataran / pelatihan-pelatihan, kualifikasi pendidikan, pembaharuan kurikulum, penerapan model atau metode pembelajaran, pengadaan buku-buku berkualitas, penelitian tentang kesulitan atau kesalahan-kesalahan yang dilakukan oleh peserta didik. Namun berbagai upaya tersebut belum memberikan hasil yang optimal, terkendala berbagai halangan pada pelaksanaannya di lapangan. Akibatnya, hingga sekarang ini kualitas pembelajaran matematika di Indonesia masih rendah.

Ruseffendi (1989:9) mengemukakan sepuluh faktor yang mempengaruhi keberhasilan seseorang dalam belajar. Faktor-faktor tersebut adalah sebagai berikut: (1) kecerdasan, (2) kesiapan belajar, (3) bakat, (4) kemauan belajar, (5) minat, (6) cara penyajian materi pembelajaran, (7) pribadi dan sikap pengajar, (8) suasana pengajaran, (9) kompetensi pengajar, dan (10) kondisi masyarakat luas.

Tingginya ekspektasi Pemerintah yang tertuang dalam kurikulum, berbanding terbalik dengan realitas nyata yang ada dilapangan sejauh ini, dimana sekolah menengah dan sekolah tinggi-pun masih mengunakan metode lama yang ditengarai dapat menurunkan standar pendidikan. Penelitian ini dilakukan oleh dosen pengampu matakuliah analisis Real yang sudah memahami karakter dari mahasiswa sebagai subyek penelitian tersebut. Sesuai dengan hasil observasi awal pada bulan maret 2018 kegiatan PBM (Proses Belajar Mengajar) yang ditemukan oleh peneliti saat kegiatan pembelajaran berlangsung, peneliti menemukan aktivitas mahasiswa masih dalam lingkup mencatat dan melakukan kegiatan sesuai dengan perintah dosen saja. Sehingga mahasiswa terlihat pasif dalam PBM (Proses Belajar Mengajar) hal ini menyebabkan mahasiswa terbatas pada mendengar, mencatat dan menjawab ketika dosen memberikan pertanyaan dan mahasiswa hanya bekerja atas perintah dosennya saja. Sedangkan, dalam pembelajaran matematika mengharuskan mahasiswa memiliki konsep 
berpikir yang mendasar, luas dan terstruktur sehingga ini juga tidak sesuai dengan tujuan pendidikan nasional.

Proses belajar mengajar seperti ini tidak mendorong mahasiswa berpikir kritis dan berkreatifitas, hal ini tidak sesuai dengan hakikat pribadi mahasiswa sebagai subjek belajar yang lebih tinggi. Dengan dasar itu pembelajaran mahasiswa harus membangun sendiri pengetahuan mereka melalui keterlibatan aktif dalam proses belajar mengajar, mahasiswa sebagai pusat kegiatan pembelajaran bukan dosen. Apalagi jika dikaitkan dengan era revolusi industri 4.0 dimana manusia dituntut berpikir kritis dengan memanfaatkan media dan teknologi terbarukan abad ini.

Belajar adalah proses yang ditandai dengan adanya perubahan pada diri seseorang sebagai proses hasil belajar dapat ditunjukkan dalam berbagai bentuk seperti perubahan pengetahuannya, pemahamannya, sikap dan tingkah lakunya, keterampilannya, kecakapan dan kemampuannya, daya reaksinya, daya penerimaannya dan aspek lain yang ada pada individu (Sudjana:2004). Sehingga perlu bimbingan ekstra dari pendidik untuk mendidik dan mengembangkan kegiatan belajar yang lebih baik dan efisien.

Berdasarkan latar belakang di atas peneliti ingin menerapkan metode pembelajaran yang efektif untuk digunakan dalam proses belajar mengajar dengan melakukan suatu penelitian berjudul "Metode Inquiri Dalam Meningkatkan Konsep Berpikir Mahasiswa Pada Materi Sistem Bilangan Real”.

\section{METODE PENELITIAN}

Konsep penelitian yang akan dilaksanakan sesuai dari latar belakang yang ada dari permasalahan upaya meningkatkan pemahaman konsep berpikir ini, sesuai dengan kriteria jenis Penelitian Tindakan Kelas (PTK), yang dilaksanakan di semester IV kelas A-B tahun akademik 2017-2018, dimana merupakan jenis penelitian partisipatif yang berkolaboratif dengan antara peneliti dan dosen pengampu matakuliah. Subyek penerima tindakan penelitian ini adalah mahasiswa kelas A-B dengan jumlah siswa 45 orang terdiri dari 25 mahasiswi dan 20 mahasiswa. Dan objek dalam penelitian ini adalah penerapan metode inquiri dalam meningkatkan pemahaman konsep berpikir, peneliti menggunakan metode inquiri karena metode ini akan membawa mahasiswa untuk lebih aktif, sebab metode inquiri menggiring mahasiswa untuk menemukan sendiri jawaban dari pertanyaan, dan mahasiswa mudah untuk memahami suatu konsep, baik itu dengan cara kreatif maupun dengan cara lain. 
Penelitian ini merupakan Penelitian Tindakan Kelas (PTK), karena data yang dikumpulkan berupa data verbal dan numerikal yang bertujuan untuk memperbaiki pembelajaran di kelas, terutama sebagai suatu upaya untuk meningkatkan konsep berpikir mahasiswa. Dalam penelitian ini peneliti sebagai instrumen utama karena peneliti yang merencanakan, merancang, melaksanakan, mengumpulkan data, menarik kesimpulan dan membuat laporan.

\section{HASIL DAN PEMBAHASAN}

Berdasarkan hasil penelitian yang telah dilakukan bahwa pada saat perlakuan awal pada silkus I hasil belajar mahasiswa yang tuntas secara individu 29 orang sementara mahasiswa yang tidak tuntas sebanyak 8 orang dengan presentase klasikalnya hanya mencapai 75,41 \%. Dengan demikian presentase ketuntasan klasikal ini dapat dikatakan masih rendah dari jumlah mahasiswa tuntas secara individu.

Selanjutnya pada siklus II diperoleh ketuntasan individu sebanyak 38 orang dari 45 orang mahasiswa yang mengikuti tes, sedangkan yang tidak tuntas sebanyak 4 orang dengan presentase ketuntasan klasikalnya 93,48 \%. Peningkatan yang dicapai pada siklus II merupakan hasil kerja keras dosen dalam upaya memperbaiki kesalahan-kesalahan yang dilakukan sebelumnya. Adapun kekurangan-kekurangan tersebut masih berkisar pada kurang mengoptimalkan peran dosen dalam membimbing dan mengarahkan mahasiswa serta menciptakan suasana belajar yang kondusif dan pengontrolan secara intensif terhadap kegiatan mahasiswa masih kurang. Untuk lebih jelas dapat dilihat pada tabel berikut:

Tabel 1. Kemampuan Konsep Berpikir Mahasiswa

\begin{tabular}{lcc}
\hline \multicolumn{1}{c}{ Tindakan } & Tuntas & Belum Tuntas \\
\hline Siklus I & $75,41 \%$ (29 siswa) & $23,19 \%$ (8 siswa) \\
Siklus II & $93,48 \%$ (38 siswa) & $7,89 \%$ (4 siswa) \\
\hline
\end{tabular}

Berdasarkan data pada tabel di atas, tampak bahwa hasil belajar siswa yang dicapai pada tindakan II mengalami peningkatan sebesar 93,48 \% (38 siswa) yang mencapai KKM. Berdasarkan indikator kerja atau indikator keberhasilan dalam penelitian ini, yaitu: hasil belajar siswa dianggap berhasil meningkat secara klasikal, apabila hasil tes yang dicapai siswa dalam suatu siklus dibandingkan dengan hasil belajar sebelum menerapkan 
pembelajaran dengan problem posing mengalami peningkatan minimal $85 \%$ siswa yang sudah mencapai $\mathrm{KKM}=75$.

\section{KESIMPULAN}

Ada peningkatan hasil belajar mahasiswa dengan cara belajar dengan menggunakan metode inquiri. Hal ini menunjukkan bahwa jika cara belajar mahasiswa baik dan benar maka berhubungan dengan hasil belar mahasiswa. Hal ini dapat dilihat dari peningkatan pemahaman setiap siklus yaitu pada siklus I mahasiswa tuntas belajar persentasi ketuntasan $75,41 \%$ dan pada siklus II mahasiswa mencapai ketuntasan dengan persentasi 93,48\%.

\section{REKOMENDASI}

Berdasarkan hasil penelitian dengan penerapan model problem posing ini, peneliti merekomendasikan dalam penerapan metode Inquiri untuk meningkatkan hasil belajar siswa dalam penelitian ini masih terbatas, untuk itu perlu adanya penelitian lanjutan dengan masalah yang lain.

\section{UCAPAN TERIMAKASIH}

Puji syukur penulis panjatkan kehadirat Allah SWT yang telah mencurahkan nikmat, diantaranya nikmat sehat dan kesempatan. Berkat nikmat sehat dan kesempatan, penulis mampu berpikir dan berbuat dalam menyelesaikan penelitian hingga pembuatan laporan hasil penelitian.

\section{REFERENSI}

Aqib, Z. (2009). Penelitian Tindakan Kelas. Bandung : Yrama Media.

Sudjana, N. (2004). Dasar-Dasar Proses Belajar Mengajar. Bandung: Sinar Baru Algensindo Ruseffendi, E.T. (1988). Pengajaran Matematika Modern dan Masa Kini (seri kedua).

Bandung: Tarsito. 